\title{
К ВОПРОСУ О ПРАВОВОМ РЕГУЛИРОВАНИИ БРАЧНО-СЕМЕЙНЫХ ОТНОШЕНИЙ В РОССИЙСКОЙ ФЕДЕРАЦИИ
}

Аннотация. В настоящей статье авторами поднимается вопрос о необходимости укрепления института семьи и брака. На основе анализа норм законодательства, в части института расторжения брака определяется ряд мер, способствующих преодолению негативных тенденций в сфере семьи и брака. Исследовалось отечественное законодательство на разных этапах развития нашей страны, в области института защиты материнства и детства, а также института расторжения брака. Видится необходимым применять процедуру медиации по всей РФ, а не в части. Методологическую основу исследования составляет совокупность общенаучных и частно-научных методов: системно - структурный, синтеза и анализа, формально - юридический, логический и сравнительно - правовой. С целью защиты материнства и детства авторами предлагается увеличение срока ограничения права супруга на предъявление требования о расторжении брака без согласия супруги; увеличение количества субъектов, а возможно и организаций осуществляющих деятельность по оказанию процедуры медиации (с участием медиаторов или без) в указанных регионах нашей страны и др.

Ключевые слова: семья, материнство, брак, процедура медиации, медиатор, детство, расторжение брака, ограничение права, супруги, примерительный срок.

Abstract. The authors consider the problem of necessity to strengthen the institution of marriage and family. The authors analyze legal provisions related to the institution of divorcing, and define the measures which help to overcome negative tendencies in the sphere of marriage and family. The authors study the Russian legislation of different periods of its development concerning the institution of maternity and childhood protection and the institution of divorcing. In the authors' opinion, it is necessary to apply the mediation procedure throughout Russia. The research methodology comprises the set of general and special scientific methods including system-structural, synthesis, analysis, technical, logical, and comparative-legal. For the purpose of maternity and childhood protection, the authors offer to prolong the term restricting the right of the spouse to make a demand for dissolution of marriage without the consent of another spouse; to increase the number of subjects and organizations involved in the mediation procedure (with or without mediators) in particular regions of the country.

Key words: conciliation period, spouses, restriction of right, divorcing, childhood, mediator, mediation procedure, marriage, maternity, family.

$\mathrm{B}$ последнее время в отечественных научных публикациях часто встречается термин «кризис семьи» как кризис социального института, системы ценностей семейственности. Внешне это выражается посредством исчезновения семейного образа жизни, либерализации брачно-семейной морали, возникновения альтернативных моделей семьи, стандартизации брачно-семейных отношений по западному образцу, в виде стабильно высокого уровня показателя разводов.

В соответствии с так называемым «нормативистским подходом» [1], «идеальной» моделью семьи для сравнительного анализа и мониторинга отклоняющихся проявлений будет служить традиционная модель, сложившаяся исторически.
Для исторически сформировавшейся модели российской семьи характерны родственно-семейный принцип организации жизни, находящейся под сильным влиянием религии, предпочтение ценности родства над собственными выгодами, семейный авторитет, иерархический порядок, моногамия, субординация в отношениях мужа и жены, многодетность. Возможность расторжения брака существует, но обществом не поддерживается, поскольку, исходя из христианского мировоззрения, единственным основанием для прекращения брака может быть только смерть одного из супругов.

Некоторые исследователи полагают, что происходящие изменения в социальном институте семьи необратимы [2]. 
Другими признается, что «кризис семьи» для России не нов, что и в прежние времена, особенно кризисные, в частности, годы разрухи, последовавшие после Октябрьской революции и гражданской войны в России, «социальный институт семьи испытывал серьезные потрясения, побуждавшие многих говорить о «кризисе семьи», но она всетаки выживала в самых тяжелых условиях и продолжала выполнять свои основные функции, пусть и в измененной форме» [3].

Встречается мнение, что именно коренная перестройка советского периода явилась причиной тех изменений в семье, которые мы наблюдаем в настоящее время [4].

В любом случае, на первый план выходит проблема укрепления семейных основ бытия, поскольку традиционно семья выступает фундаментом построения всего общества.

Одним из важнейших средств, способствующих преодолению негативных тенденций в сфере семьи и брака, является совершенствование семейного законодательства.

Как показывает ретроспективный анализ проблемы формирования и развития правовых механизмов регулирования отношений в сфере семьи и брака, в дореволюционный период дела о браке и брачных отношениях в большей мере подлежали ведомству церкви.

Первыми законодательными актами советского периода по вопросам семьи и брака стали Декрет ВЦИК, СНК РСФСР от 18.12.1917 «О гражданском браке, детях и о ведении книг актов гражданского состояния» и Декрет ВЦИК, СНК РСФСР от 19.12.1917 «О расторжении брака», в соответствии с которыми теперь признавались только гражданские браки; светской и общедоступной устанавливалась процедура расторжения брака.

В целях урегулирования правовых отношений, вытекающих из брака, семьи и опеки на основе нового революционного быта, для обеспечения интересов матери и особенно детей и уравнения супругов в имущественном отношении и в отношении воспитания детей с 1 января 1927 года был введен в действие Кодекс законов о браке, семье и опеке РСФСР 1926г., положения которого распространялись на лиц, состоящих в незарегистрированных фактических брачных отношениях.

Указом Президиума Верховного Совета СССР от 08.07.1944 г. «Об увеличении государственной помощи беременным женщинам, многодетным и одиноким матерям, усилении охраны материнства и детства, об установлении высшей степени отличия - звания «Мать-героиня» и учреждении ордена «Материнская слава» и медали «Медаль материнства»» единственным способом юридического признания фактического брака устанав- ливалась его регистрация брака в органах записи актов гражданского состояния с указанием срока совместной жизни.

В числе главных задач Кодекса о браке и семье РСФСР 1969г. провозглашалось укрепление советской семьи, всемерная охрана и поощрение материнства, обеспечение счастливого детства.

Заявленным задачам укрепления семьи всего советского периода противоречило упрощение процедуры расторжения брака. Несмотря на то, что развод считался серьезным общественным проступком, количество разводов возрастало, брачносемейная мораль девальвировалась.

Недопустимость предъявления мужем требования о расторжении брака устанавливалась только на время беременности жены и в течение одного года после рождения ребенка без соответствующего на то согласия жены (ст.31 Кодекса о браке и семье РСФСР 1969г.).

Начиная с 1996г., действует Семейный Кодекс Российской Федерации (далее - СК РФ), регулирующий брачно-семейные отношения, в том числе по вопросам заключения и прекращения брака.

Свобода и простота расторжения брака попрежнему выступает в разрез с задачей укрепления института брака и семьи.

В соответствии с СК РФ, расторжение брака производится в органах ЗАГС и в судебном порядке.

Административный порядок, как правило, не предусматривает выяснения истинных причин прекращения семейных отношений и не включает в себя примирительные процедуры. По сути, государство только констатирует факт разрушения семейных отношений, не предпринимая попыток сгладить негативные последствия расторжения брака. Это относится к компетенции суда и не входит в полномочия органов ЗАГСа. На сегодняшний день имеется мнение, что сохранение норм, регулирующих административный порядок расторжения брака, не целесообразно [5].

В целях повышения эффективности применения судом мер, направленных на сохранение семьи, в науке предлагается принятие для судей рекомендаций с примерным перечнем мотивов расторжения брака. Правильная квалификация причины развода будет способствовать объективной оценке перспективы назначения примирительного срока, определению необходимых средств по урегулированию возникшего между супругами спора [6].

Единственное ограничение права мужа на предъявление требования о расторжении брака без согласия жены, в соответствии со ст.17 СК РФ, заключается в те же временные рамки, что и ранее (во время беременности жены и в течение года после рождения ребенка) (ст.17 СК РФ). 


\section{Административное и муниципальное право 5 (101) 2016}

В юридической литературе встречается мнение, что эту норму следует дополнить в связи с необоснованностью ограничения права на расторжение брака по инициативе мужа в случае рождения мертвого ребенка, а также в случае смерти ребенка до достижения им годичного возраста положением о прекращении в этих случаях действия ограничения [5].

На наш взгляд, авторами недооценено психологическое состояние матери, безусловно находящейся в тяжелой стрессовой ситуации, переживающей безмерное горе, для которой важна поддержка близких людей. Расторжение брака по инициативе мужа во многих случаях станет фактором, усугубляющим сложившееся положение.

Отмечается, что некоторые исследователи приходят к выводу о необходимости исключения данной нормы как ущемляющей права супруга $[7,8]$.

Предлагается вариант порядка предоставления и формы выражения женой согласия на развод - его оформление в письменном виде. Но даже он не признается гарантией от изменения принятого женщиной решения [8].

О.А. Минеев, рассматривая период, в течение которого запрещена подача иска о расторжении брака мужем в суд, ставит вопрос о критерии, которым руководствовался законодатель, выделяя год после рождения ребенка: «Непонятно, почему законодатель лишает этого права мужа именно в данный период? Неужели после годовалого возраста ребенок требует меньшей заботы и материального обеспечения со стороны родителей, чем до года?» [5]

Как нам представляется, дискуссионную норму об ограничении права мужа на предъявление требования о расторжении брака во время беременности жены и в течение года после рождения ребенка, следует рассматривать с точки зрения усиления охраны детства и материнства, и соотнести с ситуацией в сфере образования, а также другими нормами права.

Как показывают исследования, в последние десятилетия происходит резкая дифференциация доходов семей. Большинство малообеспеченных семей в России - семьи трудоспособных работающих супругов, имеющих детей. В самой тяжелой ситуации оказываются семьи безработных одиноких матерей [9].

Разведенной женщине с ребенком раннего возраста на руках практически невозможно совместить его воспитание и материальное обеспечение, поскольку в этот период она практически неотлучно находится с ребенком.

Несмотря на то, что в законодательстве предусмотрена возможность получения дошкольного образования в образовательных организациях по достижении детьми возраста двух месяцев (п.1 ст.67 Федерального закона «Об образовании в Российской Федерации», далее - Закон об образовании), на практике ситуация складывается следующим образом.

В соответствии со ст.25 Закона об образовании, деятельность образовательных организаций осуществляется на основании устава, утвержденного в установленном законодательством Российской Федерации порядке, в котором регламентируются, в том числе, и правила приема детей. Вопрос о предельном минимальном возрасте принимаемых в конкретную образовательную организацию детей решается каждым отдельным детским учреждением самостоятельно.

Как показывает практика, в подавляющем большинстве случаев детей принимают в детскую образовательную организацию по достижении ими возраста двух лет, реже - трех лет (для г. Москвы).

На основании п.4 ст.67 Закона об образовании, в приеме в государственную или муниципальную образовательную организацию может быть отказано по причине отсутствия в ней свободных мест.

Фактически, до достижения ребенком двухтрех лет женщина вынуждена жить на ежемесячное пособие по уходу за ребенком до 1.5 лет, алименты бывшего мужа.

Вряд ли стоить упоминать о сложившейся ситуации с выплатами алиментов. По опубликованным в «Обзоре об итогах работы с обращениями граждан и представителей организаций и личному приему за 9 месяцев 2015 года» данным ФССП, за 9 месяцев 2015г. зафиксировано 31291 обращений по вопросам взыскания алиментных платежей [10].

По информации УФССП России по Московской области, абсолютное большинство граждан - должников трудоспособны, «но мер к погашению образовавшихся задолженностей по уплате алиментов на содержание детей, как правило, не принимают, и встать на учет в центр занятости населения в качестве безработных не пытаются» [11].

Следует отметить, что семейным законодательством предусмотрена обязанность бывшего супруга по содержанию не только своих несовершеннолетних детей, но и, в соответствии со ст.90 СК РФ, по содержанию жены - в течение трех лет со дня рождения общего ребенка.

Этот же срок - до достижения ребенком трех лет устанавливается в трудовом законодательстве для обеспечения женщине социальных гарантий. Так, в соответствии со ст.256 Трудового Кодекса РФ, по заявлению женщины ей предоставляется отпуск по уходу за ребенком до достижения им возраста трех лет.

Как нам представляется, период ограничения права мужа на предъявление требования о расторжении брака также следует увеличить, изложив 
ст.17 СК РФ в следующей редакции: «Муж не имеет права без согласия жены возбуждать дело о расторжении брака во время беременности жены и в течение трех лет после рождения ребенка».

По нашему мнению, это будет способствовать не только цели сохранения семьи и брака, защите материнства и детства, но установлению единого режима правового регулирования для отношений такого рода.

Еще одним важным направлением совершенствования семейного законодательства может стать применение альтернативной процедуры урегулирования споров при расторжении брака. Поскольку целью медиации в этом случае будет являться снижение уровня расторжения браков, укрепление семьи как социального института, а также снижение нагрузки на судебный аппарат, является обоснованным внесение предлагаемых законодателем поправок в Федеральный закон РФ «Об альтернативной процедуре урегулирования споров с участием посредника (процедуре медиации)» о введении обязательной досудебной процедуры медиации по спорам о расторжении брака между супругами, имеющими несовершеннолетних детей, или в случае несогласия одного из супругов на расторжение брака[6]. Законодатель приводит Справку о практике применения судами Федерального закона РФ выше указанного за период с 2013 по 2014 год, утвержденную Президиумом Верховного Суда РФ от 01 апреля 2015г, где положительно характеризуются, пользуются широким спросом процедуры медиации и услуги медиатора (как платные, так и бесплатные).
Подводя итоги исследования, необходимо обратить внимание на тот потенциал, который содержит в себе совершенствование отечественного семейного законодательства для преодоления негативных тенденций в сфере семьи и брака.

Существует комплекс мер, способствующий укреплению института семьи и брака, среди которых:

- принятие предложенных специалистами рекомендаций для судей с примерным перечнем мотивов расторжения брака в целях объективной оценки перспективы назначения примирительного срока, определения средств по урегулированию возникшего между супругами спора;

- $\quad$ увеличение срока ограничения права супруга на предъявление требования о расторжении брака без согласия супруги во время беременности;

- применение альтернативной процедуры урегулирования споров при расторжении брака (процедура медиации, с участием медиатора) в больших количествах субъектов Российской Федерации. На сегодняшний день указанная процедура (своего рода досудебное соглашение) проводиться более чем в 60 субъектах РФ (что следует из справки приведенной выше), видится необходимым увеличить количество субъектов, а возможно и организации осуществляющие деятельность по оказанию процедуры медиации в указанных регионах нашей страны и др.

Следует применять все возможные меры для изменения ситуации, сложившейся в сфере брачно-семейных отношений.

\section{Библиография:}

1. Ляушева С.А. Влияние модернизации общества на институт семьи // Вестник Адыгейского государственного университета. Серия 1: Регионоведение: философия, история, социология, юриспруденция, политология, культурология . 2010. №2. С.105-110.

2. Синельников А.Б. Семья и брак на европейском фоне.//Мониторинг. 2010. №4[98]. С.53-76.

3. Афасижев Т.И., Хрупин С.И. Семейно-брачные отношения в современном социокультурном пространстве России: региональный аспект// Вестник Адыгейского государственного университета. Серия 1: Регионоведение: философия, история, социология, юриспруденция, политология, культурология . 2009. №2. С.52-60.

4. Замараева З.П., Новоселов В.М. Особенности трансформации института отцовства в советский период // Теория и практика общественного развития . 2012. №6. С.53-56.

5. Минеев О.А. К вопросу о совершенствовании института брака в семейном праве Российской Федерации // Вестник ВолГУ. Серия 5. Юриспруденция.-2015. №2 (27). С. 113-116.

6. Ц Цветков В.А. Мотивы расторжения брака по российскому семейному праву // Вестник Омской юридической академии. - 2013. - № 1 (20). - С. 51-53.

7. Климова С.А. Личное неимущественное право супруга на расторжение брака и его реализация в судебном порядке// «Семейное и жилищное право», 2007, №3. С.12-15.

8. Сенькин В.А. Об особенностях возбуждения и рассмотрения в суде дел о расторжении брака// Юридическая наука. 2011. №1. С.58-60.

9. Фролкин П.П., Мауталиев Р.В. Региональные аспекты государственной политики социальной защиты материнства и детства в России // Власть. №5, 2012. С.30-33.

10. Обзор об итогах работы с обращениями граждан и представителей организаций и личному приему за 9 месяцев 2015 года / Федеральная служба судебных приставов / http://fssprus.ru/2229727/

11. Неуплата алиментов влечет за собой уголовную ответственность. 21.10.2014. Пресс-служба УФССП России по Московской области / http://r50.fssprus.ru/news/document22516138 


\section{Административное и муниципальное право 5 (101) • 2016}

12. К.С. Шибаева Взаимосвязь супружеских взаимоотношений и совладающего поведения мужчин в бесплодном браке // Психология и Психотехника. - 2011. - 12. - С. 21 - 27.

\section{References (transliterated):}

1. Lyausheva S.A. Vliyanie modernizatsii obshchestva na institut sem'i // Vestnik Adygeiskogo gosudarstvennogo universiteta. Seriya 1: Regionovedenie: filosofiya, istoriya, sotsiologiya, yurisprudentsiya, politologiya, kul'turologiya . 2010. №2. S.105-110.

2. Sinel'nikov A.B. Sem'ya i brak na evropeiskom fone.//Monitoring. 2010. №4[98]. S.53-76.

3. Afasizhev T.I., Khrupin S.I. Semeino-brachnye otnosheniya v sovremennom cotsiokul'turnom prostranstve Rossii: regional'nyi aspekt// Vestnik Adygeiskogo gosudarstvennogo universiteta. Seriya 1: Regionovedenie: filosofiya, istoriya, sotsiologiya, yurisprudentsiya, politologiya, kul'turologiya . 2009. №2. S.52-60.

4. Zamaraeva Z.P., Novoselov V.M. Osobennosti transformatsii instituta ottsovstva v sovetskii period // Teoriya i praktika obshchestvennogo razvitiya . 2012. №6. S.53-56.

5. Mineev O.A. K voprosu o sovershenstvovanii instituta braka v semeinom prave Rossiiskoi Federatsii // Vestnik VolGU. Seriya 5. Yurisprudentsiya.-2015. №2 (27). S. 113-116.

6. Tsvetkov V.A. Motivy rastorzheniya braka po rossiiskomu semeinomu pravu // Vestnik Omskoi yuridicheskoi akademii. 2013. - № 1 (20). - S. 51-53.

7. Klimova S.A. Lichnoe neimushchestvennoe pravo supruga na rastorzhenie braka i ego realizatsiya v sudebnom poryadke// «Semeinoe i zhilishchnoe pravo», 2007, №3. S.12-15.

8. Sen'kin V.A. Ob osobennostyakh vozbuzhdeniya i rassmotreniya v sude del o rastorzhenii braka// Yuridicheskaya nauka. 2011. №1. S.58-60.

9. Frolkin P.P., Mautaliev R.V. Regional'nye aspekty gosudarstvennoi politiki sotsial'noi zashchity materinstva i detstva $\mathrm{v}$ Rossii // Vlast'. №5, 2012. S.30-33.

10. Obzor ob itogakh raboty s obrashcheniyami grazhdan i predstavitelei organizatsii i lichnomu priemu za 9 mesyatsev 2015 goda / Federal'naya sluzhba sudebnykh pristavov / http://fssprus.ru/2229727/

11. Neuplata alimentov vlechet za soboi ugolovnuyu otvetstvennost'. 21.10.2014. Press-sluzhba UFSSP Rossii po Moskovskoi oblasti / http://r50.fssprus.ru/news/document22516138

12. K.S. Shibaeva Vzaimosvyaz' supruzheskikh vzaimootnoshenii i sovladayushchego povedeniya muzhchin $\mathrm{v}$ besplodnom brake // Psikhologiya i Psikhotekhnika. - 2011. - 12. - C. 21 - 27. 